\title{
nature
}

\section{Reasons to be cloned}

Current debates on human cloning have been stimulated by questionable achievements. All the more reason for proponents of cloning for biomedical research to articulate the full range of potential benefits.

$\mathrm{H}$ uman reproductive cloning is widely reviled by cloning experts, who fear that the resulting children will be malformed, if they are born at all. This idea is based on the large number of miscarriages and defective offspring reported in cloned animals. So even without venturing into the debate about whether we would be comfortable having cloned humans for neighbours (or as offspring, or being clones ourselves), the health risks to mother and child inherent in this practice demand that it be banned. But many argue that the prohibitions should stop with reproductive cloning.

The recent announcement by the company Advanced Cell Technology (ACT) in e-biomed: The Journal of Regenerative Medicine that it has cloned a human embryo consisting of six cells is regarded as premature by many cloning experts. They say ACT's embryo may be no more than an activated egg, and is devoid of embryonic stem cells. ACT wants to develop cell transplantation therapies targeted to individual patients, by stimulating eggs to form embryos that are genetically identical to adult donor cells. It is anyone's guess whether ACT's announcement was intended to lend transparency to its activities or to publicize them. And the publication has led to a resignation from the journal's editorial board (see page 570). These events highlight the urgency of passing legislation to regulate human cloning.

Stem-cell scientists at ACT and elsewhere need only allow a cloned embryo to develop for five days until it becomes a hollow ball of 100 or so cells. This 'blastocyst' contains no organs or nervous tissue, but possesses a few highly prized embryonic stem (ES) cells, which can be extracted and cultured. ES cells are unique in their ability to continually replenish themselves and, under the right conditions, to form every cell and tissue type in the body.

Such research could fundamentally transform the study of human disease. But whereas the years of culturing embryos in fertility clinics may have brought the first stage of therapeutic cloning that is, generating ES cells from cloned embryos - closer to hand, scientists are a long way from understanding how these cells can be grown into organs and tissues for patient transplants. And the economic feasibility of the approach requires scrutiny: there may be other solutions to the problem of graft rejection that would obviate the need to make cloned embryos from patients.

The ability to grow and study ES cells from patients may also further our understanding of why some people get diseases whereas others don't - a notion that hasn't been adequately discussed in the human-cloning debate. Researchers are starting to think about how certain combinations of genetic mutations that occur in our somatic cells and in the germ cells of our parents could predispose us to disease, and influence the age at which we develop the disease and how long we survive. For example, one way to study a disease such as Parkinson's at a molecular level would be to set up ES-cell lines from a patient and from controls, grow them into large quantities of dopaminergic neurons in Petri dishes, and find out why the patient's cells die. The next step would be to determine how to keep them alive. ES-cell cultures cloned from patients could also provide a virtually limitless supply of diseased cells for drug screening and gene-therapy trials.

For such research, it would be essential that work involving human cloning is subject to strict supervision and regulation to ensure that it falls within ethically acceptable boundaries. It may be necessary to address the concern that embryos used in research might lead to the birth of a child, perhaps by developing methods that prevent cloned embryos from ever completing gestation, as ACT is attempting to do by using parthenogenesis to generate embryos .

The US Senate is likely to vote on a bill to ban human cloning when it reconvenes in early January. It is crucial that, before this bill reaches the Senate floor, there is informed debate between scientists, bioethicists, politicians and the public, focusing on the use of human blastocysts for research. Now is a good time for scientists carefully to consider and communicate to the public the benefits of allowing such research, and to offer guidance on how it could be regulated to prevent ethical breaches.

\section{Welcome SciDev.Net}

This week sees the launch of an independent website for the developing world.

$\mathrm{T}$ he exclusion of large parts of the world's population from many of the benefits of science and technology is a critical issue in international affairs. We are therefore pleased to announce our support for a new independent website, SciDev.Net, launched this week, which will provide a forum for authoritative news, information and comment about how science and technology can help meet the needs of developing nations. Although the site has been in gestation for more than a year, its appearance now could hardly be more timely. The range of potential topics to be addressed is broad, from global warming to genetically modified crops. The spirit is one of dialogue: it is as important to transmit perspectives held in the developing world as it is to convey those of 'the North'.

We have been closely involved in the incubation of SciDev.Net and (together with the journal Science) will be providing free access each week to selected articles from our pages. Support and guidance is being given by the Third World Academy of Sciences, and funding generously provided by the UK Department for International Development, the Swedish International Development Cooperation Agency and the International Development Research Centre in Canada.

We hope that the information and perspectives offered by SciDev.Net will both strengthen the hands of policy-makers and empower individuals and communities, leading to sounder decision-making at all levels of society. By doing so, the website aims to help bridge the gap between the 'haves' and 'have-nots' in science and technology in development. We invite you to show your support by visiting the website (www.scidev.net), registering your interest, and engaging in the debates that we hope it will stimulate. 